Research Paper: Gerotarget (Focus on Aging)

\title{
Octogenarians with EGFR-mutated non-small cell lung cancer treated by tyrosine-kinase inhibitor: a multicentric real-world study assessing tolerance and efficacy (OCTOMUT study)
}

\author{
Romain Corre ${ }^{1,12}$, Radj Gervais ${ }^{2}$, Florian Guisier ${ }^{3}$, Louis Tassy $^{4}$, Florent Vinas ${ }^{5}$, \\ Régine Lamy6, Gislaine Fraboulet7, Laurent Greillier ${ }^{8}$, Helene Doubre ${ }^{9}$, Renaud \\ Descourt $^{10}$, Christos Chouaid ${ }^{5}$ and Jean-Bernard Auliac ${ }^{11}$ \\ ${ }^{1}$ Department of Pneumology, CHU Pontchaillou, Rennes, France \\ 2 Pneumo-Oncology Department, Centre Francois Baclesse, Caen, France \\ ${ }^{3}$ Pneumology Department, CHU Hôpitaux de Rouen-Charles Nicolle, Rouen, France \\ ${ }^{4}$ Oncology Department, Institut Paoli-Calmette, Marseille, France \\ ${ }^{5}$ Pneumology Department, $\mathrm{CH}$ Intercommunal de Créteil, Créteil, France \\ ${ }^{6}$ Oncology Department, CH Sud-Bretagne, Lorient, France \\ 7 Pneumology Department, Hôpital René-Dubos, Pontoise, France \\ ${ }^{8}$ Pneumo-Oncology Department, Hôpital Sainte-Marguerite, Assistance Publique-Hôpitaux de Marseille, Marseille, France \\ 9 Pneumology Department, Hôpital Foch, Suresnes, France \\ ${ }^{10}$ Cancerology Institute, $\mathrm{CHU}$ Brest, Brest, France \\ ${ }^{11}$ Pneumology Department, CH François Quesnay, Mantes La Jolie, France \\ 12 UMR INSERM U1242-COSS, Rennes University, Rennes, France \\ Correspondence to: Romain Corre, email: romain.corre@chu-rennes.fr \\ Keywords: targeted therapies; tyrosine-kinase inhibitors; non-small cell lung cancer; EGFR; elderly; Gerotarget \\ Received: September 22, $2017 \quad$ Accepted: November 13, $2017 \quad$ Published: January 02, 2018
}

Copyright: Corre et al. This is an open-access article distributed under the terms of the Creative Commons Attribution License 3.0 (CC BY 3.0), which permits unrestricted use, distribut3ion, and reproduction in any medium, provided the original author and source are credited.

\section{ABSTRACT}

Objective. To assess efficacy and tolerance of EGFR tyrosine-kinase inhibitors (TKIs) for advanced EGFR-mutated non-small cell lung cancer (NSCLC) in octogenarians.

Patients and methods. Patients aged 80 years or older with EGFR-mutated NSCLC treated by EGFR TKI between January 2011 and March 2015 whatever the line of treatment were retrospectively selected.

Results. 20 centers retrospectively included 114 patients (women, 77.2\%; Caucasians, 98.3\%; mean age, 83.9 years). A performance status of $0-1$ or 2-3 at diagnosis was reported for $\mathbf{7 1 . 6 \%}$ and $\mathbf{2 8 . 4 \%}$ of patients, respectively. Overall, $95.6 \%$ of patients had adenocarcinomas and histological stage at diagnosis was stage IV for $79.8 \%$ of patients. EGFR mutations were identified mainly on exon $19(46.5 \%)$ and exon $21(40.4 \%)$. A geriatric assessment was performed in $35.1 \%$ of patients. TKI treatment was administered to $\mathbf{9 7 . 3 \%}$ of patients as first or second line of treatment. Overall response rate and disease control rate were $63.3 \%(69 / 109)$ and $78.9 \%$ (86/109), respectively. Median progression-free survival was 11.9 months (95\% confidence interval $[\mathrm{CI}], 8.6-14.7$ ) and median overall survival was 20.9 months (95\% CI, 14.3-27.1). After progression, 36/95 (37.9\%) patients received a new line of chemotherapy. Main toxicities were cutaneous for $66.7 \%$ of patients (grade $3-4,10 \%$ ), diarrhea for $56.0 \%$ (grade 3-4, 15\%; grade 5, 2\%) and others for $25.7 \%$ (grade 3-4, 41\%).

Conclusions. Octogenarians with EGFR-mutated NSCLC treated by EGFR TKI had clinical outcomes and toxicity profile comparable to younger patients. Geriatric assessment appeared to be underused in this population. 


\section{INTRODUCTION}

Lung cancer is the most common cancer worldwide and is the leading cause of cancer death in Western countries [1]. Among the different forms of lung cancer, non-small cell lung cancer (NSCLC) is the most common $(80-85 \%)$. However, NSCLC is often diagnosed when metastases are present or when the disease is at an advanced stage. In about half of the cases, NSCLC is diagnosed in patients $>65$ years and in $30-40 \%$ of the cases in patients $>70$ years [2]. With the growing of aging population, elderly patients with lung cancer will be more frequent [3].

According to the last guidelines from the European Society for Medical Oncology (ESMO), it is recommended to use carboplatin based-doublet treatment in fit elderly patients with NSCLC $[4,5]$. In elderly patients who are less fit, single agent therapy (vinorelbine, gemcitabine or taxane) is an option [6-8]. Nevertheless, over 80 years, there are no firm recommendations because data on NSCLC treatment are scarce in this population of patients.

Erlotinib was the first EGFR tyrosine-kinase inhibitor (TKI) to be approved in advanced stage NSCLC after failure of first-line chemotherapy with platinum. The BR.21 study showed a benefit for progression-free survival (PFS) and overall survival (OS) with erlotinib after failure of first- or second-line therapy [9]. The drawback was a significant higher rate of grade 3-5 toxic effects in older patients (35\% in patients $\geq 70$ years vs. $18 \%$ in patients $<70$ years) [10]. In 2004, Lynch et al demonstrated that EGFR mutations were predictors of a response to EGFR TKI that, in addition, was often intense and fast [11]. Therefore, screening EGFR mutations offered the possibility to select patients who would respond to EGFR
TKI. Many studies confirmed the superiority of EGFR TKIs for PFS in comparison with a platin based-doublet in patients with advanced NSCLC harboring an activating EGFR mutation in first-line setting [12-18]. On this basis, gefitinib, erlotinib and the more recent afatinib were approved for the first-line treatment of advanced NSCLC in patients harboring an activating EGFR mutation.

In addition, compare to chemotherapy [13-18] the safety profiles of the different EGFR TKIs were favorable. In this setting, few data are available in patients 80 years or more because clinical studies on EGFR TKI included few elderly patients. Thus, the upper limit of age for inclusion was 75 years in the studies of Maemondo et al [14] and Zhou et al [15] and 65 years for LUX-Lung 6 study [18]. Inoue et al demonstrated that elderly patients or patients with poor performance status with advanced NSCLC harboring EGFR mutation could benefit from EGFR TKI [19]. These results were confirmed in other Asian studies, but no data about Caucasian octogenarians were available $[20,21]$.

The aim of the OCTOMUT study was to improve knowledge on the efficacy and safety of EGFR TKIs in patients 80 years or more with advanced NSCLC harboring activating EGFR mutation.

\section{RESULTS}

\section{Socio-demographic characteristics of patients}

A total of 114 patients were selected by the 20 French participating centers. Three out four patients were women $(77.2 \%)$ with a mean $(\mathrm{SD})$ age of $83.9(3.9)$ years

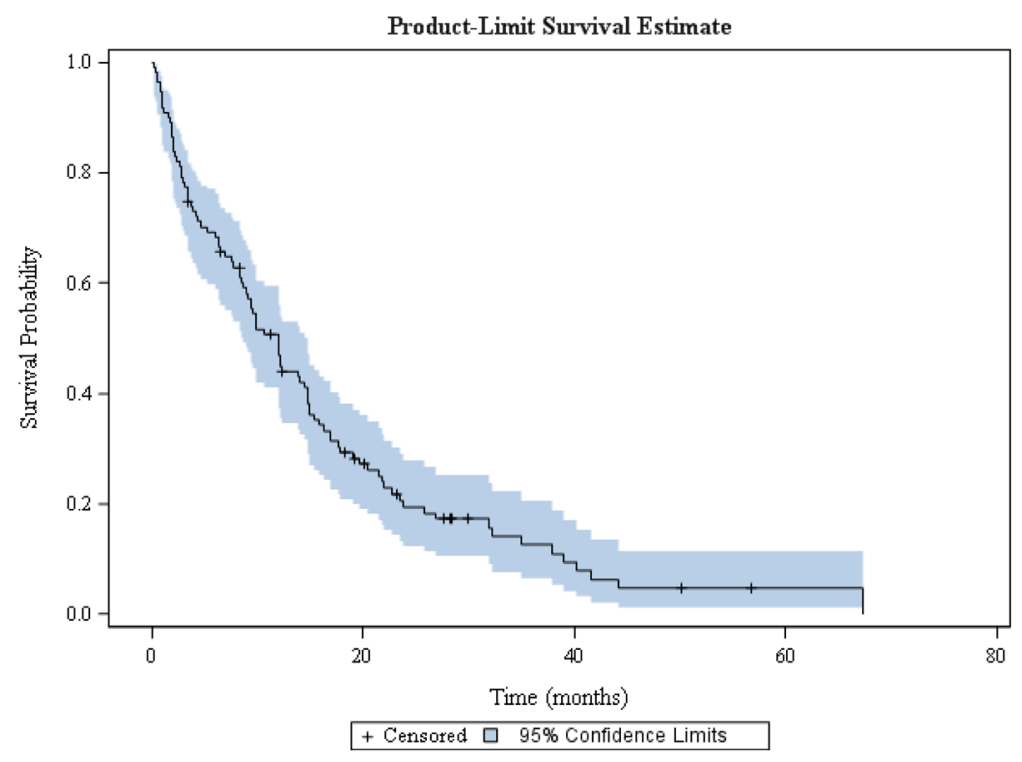

Figure 1: Progression-free survival in octogenarian patients with EGFR-mutated NSCLC treated with EGFR TKI. 
Table 1: Socio-demographic characteristics of octogenarian patients from OCTOMUT study

\begin{tabular}{|c|c|}
\hline & $\mathrm{N}=114$ \\
\hline Age (years), mean (SD) & $83.9(3.9)$ \\
\hline Women, n (\%) & $88(77.2)$ \\
\hline \multicolumn{2}{|l|}{ Body mass index $\left(\mathrm{kg} / \mathrm{m}^{2}\right)$} \\
\hline Mean (SD) & $24.5(3.9)$ \\
\hline \multicolumn{2}{|l|}{ Classes, n (\%) } \\
\hline Leanness & $2(2.4)$ \\
\hline Normal & $46(55.4)$ \\
\hline Overweight & $27(32.5)$ \\
\hline Obesity & $8(9.6)$ \\
\hline$M D$ & 31 \\
\hline Caucasians, n (\%) & $112(98.3)$ \\
\hline Non-smokers, n (\%) & $87(76.3)$ \\
\hline \multicolumn{2}{|l|}{ Performance status, n (\%) } \\
\hline $0-1$ & $73(71.6)$ \\
\hline $2-3$ & $29(28.4)$ \\
\hline$M D$ & 12 \\
\hline \multicolumn{2}{|l|}{ Number of medications, $\mathrm{n}(\%)$} \\
\hline $0-2$ & $25(23.6)$ \\
\hline $3-5$ & $41(38.7)$ \\
\hline$\geq 6$ & $40(37.8)$ \\
\hline$M D$ & 8 \\
\hline \multicolumn{2}{|l|}{ Way of life, n (\%) } \\
\hline Alone at home & $94(90.4)$ \\
\hline Retirement home & $10(9.6)$ \\
\hline$M D$ & 10 \\
\hline Charlson comorbidity index performed, $\mathrm{n}(\%)$ & $16(14.0)$ \\
\hline Geriatric assessment performed, $\mathrm{n}(\%)$ & $40(35.1)$ \\
\hline
\end{tabular}

$\mathrm{MD}$, missing data.

and $98.3 \%$ were Caucasians (Table 1). They lived at home for $90.4 \%$ (including $45.6 \%$ with some help) and $9.6 \%$ lived in retirement home. Their performance status was 0 -1 for $71.6 \%$ and $76.4 \%$ took a number of medications $\geq 3$. A Charlson comorbidity index was available in only $14.0 \%$ of patients. A geriatric assessment was performed for only $35.1 \%$ of patients including Activities of Daily Living (ADL; $n=29$ ), Instrumental Activities of Daily Living (IADLs; $n=27$ ) and Mini Mental State (MMS; $n$ $=25)$.

\section{Characteristics of NSCLC and EGFR TKI treatment}

The median time between first symptoms and diagnosis was 55.0 days (Table 2). The histological diagnosis was adenocarcinoma in $95.6 \%$. EGFR mutations were identified mainly on exon $19(46.5 \%)$ and exon 21 (40.4\%). Almost all patients $(97.3 \%)$ received EGFR TKI as first $(83.2 \%)$ or second line $(14.1 \%)$ of treatment. The main EGFR TKIs prescribed were gefitinib (54.4\%) and 
Table 2: Characteristics of NSCLC in patients from OCTOMUT study

\begin{tabular}{lc}
\hline & $\mathbf{N}=\mathbf{1 1 4}$ \\
\hline Median time (days) between first symptoms and diagnosis & 55.0 \\
Adenocarcinoma, n (\%) & $109(95.6)$ \\
Histological stage at diagnosis, n (\%) & \\
I-II & $8(7.0)$ \\
III & $15(13.2)$ \\
IV & $91(79.8)$ \\
Localization of metastases, n (\%) & \\
Pleural cavity & $43 / 91(47.3)$ \\
Lung & $29 / 91(31.9)$ \\
Lymph nodes & $18 / 91(19.8)$ \\
EGFR mutation, $\mathrm{n}(\%)$ & \\
Exon 19 & $53(46.5)$ \\
Exon 21 & $46(40.4)$ \\
Exon 18 & $9(7.9)$ \\
Exon 20 & $6(5.2)$ \\
Number of lines of treatment before EGFR TKI, $\mathrm{n}(\%)$ & \\
0 & $94(83.2)$ \\
1 & $16(14.2)$ \\
Type of EGFR TKI, $\mathrm{n}(\%)$ & $3(2.6)$ \\
Gefitinib & 1 \\
Erlotinib & $62(54.4)$ \\
Afatinib & $45(39.6)$ \\
Undefined & $2(1.8)$ \\
\hline$D$, & $5(4.2)$ \\
\hline & \\
\hline & \\
\hline & \\
\hline
\end{tabular}

MD, missing data.

erlotinib (39.5\%). The approved dose of EGFR TKI was administered to $87.2 \%(95 / 109)$ of patients.

\section{Clinical efficacy outcomes after treatment with EGFR TKI}

The overall response rate (ORR) was 63.3\% $(69 / 109)$ and the disease control rate was $78.9 \%(86 / 109)$ (Table 3). Median PFS was 11.9 months (95\% confidence interval [CI], 8.6-14.7) and median OS was 20.9 months (95\% CI, 14.3-27.1) (Figures 1-2). In $43.5 \%$ of patients who progressed according to RECIST criteria (34/78), EGFR TKI treatment was continued beyond progression for a median of 4.0 months (from 1 to 69 months);
36/95 (37.9\%) of patients received chemotherapy after EGFR TKI discontinuation (platin-based doublet and monotherapy in $61 \%$ and $39 \%$ of cases, respectively) for a mean of $3 \pm 2$ cycles. Response and disease control rates of these chemotherapies were $30 \%$ and $39 \%$ respectively.

\section{Toxicities of EGFR TKI}

Main toxicities were cutaneous $(66.7 \%$ of patients; grade $3-4,10.3 \%)$, diarrhea $(56 \%$; grade $3-5,17.0 \%)$ or others $(25.6 \%$; grade $3-4,40.9 \%$ ) (Table 4$)$. We found no factor (ie: age, BMI or number of drugs...) significantly associated with a higher toxicity. 
Table 3: Clinical efficacy outcomes in octogenarian patients after treatment with EGFR TKI (OCTOMUT study)

$$
\mathbf{N}=114
$$

Best clinical response, $\mathrm{n}(\%)$

Complete response (CR)

Partial response (PR)

$65(59.6)$

Stable disease (SD)

Progressive disease (PD)

$14(12.8)$

Not evaluated

$9(8.3)$

$M D$

Overall response rate (ORR), $\mathrm{n}(\%)^{\mathrm{a}}$

$69(63.3)$

Disease control rate $\mathrm{n}(\%)^{\mathrm{b}}$

$86(78.9)$

Overall survival (months), median (95\% CI)

$20.9(14.3-27.1)$

Progression-free survival (months), median (95\% CI)

$11.9(8.6-14.7)$

Other line of treatment after progression, $\mathrm{n}(\%)$

$36 / 95(37.9)$

MD, missing data

${ }^{\mathrm{a}} \mathrm{ORR}=\mathrm{CR}+\mathrm{PR}$

${ }^{\mathrm{b}}$ Disease control rate $=\mathrm{CR}+\mathrm{PR}+\mathrm{SD}$.

Table 4: Safety outcomes in the after treatment of octogenarian patient in the OCTOMUT study

\begin{tabular}{lcccc}
\hline & $\mathbf{N}=\mathbf{1 1 4}$ & $\begin{array}{c}\text { Gefitinib } \\
\mathbf{N}=\mathbf{6 2}\end{array}$ & $\begin{array}{c}\text { Erlotinib } \\
\mathbf{N}=\mathbf{4 5}\end{array}$ & $\begin{array}{c}\text { Afatinib } \\
\mathbf{N}=\mathbf{7}\end{array}$ \\
\hline Patients with report of toxicities & $82 / 91(90.1)$ & $39 / 44(88.6)$ & $37 / 40(92.5 \%)$ & $6 / 7(85.7 \%)$ \\
Cutaneo-mucous toxicity, n (\%) & $58 / 81(71.6)$ & $28 / 44(63.7)$ & $24 / 31(77.4)$ & $6 / 6(100)$ \\
Grade 1 & $32 / 58(55.2)$ & $18 / 30(60)$ & $13 / 22(59)$ & $1 / 6(16.7)$ \\
Grade 2 & $20 / 58(34.5)$ & $8 / 30(26.7)$ & $8 / 22(36.3)$ & $4 / 6(66.6)$ \\
Grade 3 & $6 / 58(10.3)$ & $2 / 30(6.7)$ & $3 / 22(13.7)$ & $1 / 6(16.6)$ \\
Digestive toxicity (diarrhea), n (\%) & $47 / 84(56.0)$ & $21 / 48(43.7)$ & $20 / 30(66.7)$ & $6 / 6(100)$ \\
Grade 1 & $18 / 47(38.3)$ & $9 / 21(42.9)$ & $8 / 20(40)$ & $1 / 6(16.7)$ \\
Grade 2 & $21 / 47(44.7)$ & $10 / 21(47.6)$ & $8 / 20(40)$ & $3 / 6(50)$ \\
Grade 3 & $7 / 47(14.9)$ & $3 / 21(14.2)$ & $2 / 20(10)$ & $2 / 6(33.3)$ \\
Grade 5 & $1 / 47(2.1)$ & $0 / 25(0)$ & $0 / 16(0)$ & $1 / 6(16.7)$ \\
Other toxicities, n (\%) & $19 / 74(25.7)$ & $8 / 39(25.6)$ & $6 / 30(20)$ & $5 / 5(100)$ \\
Grade 1 & $4 / 22(18.2)$ & $2 / 8(25)$ & $1 / 6(16.7)$ & $1 / 5(20)$ \\
Grade 2 & $4 / 22(40.9)$ & $4 / 8(50)$ & $3 / 6(50)$ & $2 / 5(40)$ \\
Grade 3 & $8 / 22(36.4)$ & $4 / 8(50)$ & $3 / 6(50)$ & $1 / 5(20)$ \\
Grade 4 & $1 / 22(4.6)$ & $0 / 8(0)$ & $1 / 6(16.7)$ & $0 / 5(0)$ \\
\hline
\end{tabular}




\section{DISCUSSION}

Although EGFR TKIs such as erlotinib, gefitinib or afatinib dramatically changed the history of metastatic NSCLC harboring EGFR mutations, not enough data are available on the efficacy of these targeted therapies in elderly patients and more specifically in Caucasian patients. Indeed, old age frequently prevents the realization of some diagnostic investigations and prescription of specific treatments because of fear of healthcare professionals or patients for excess toxicity and low efficiency. In clinical trials, difficulties in recruitment, management and follow-up lead to an under-representation of elderly cancer patients [23].

To our knowledge, the present retrospective multicenter study is the largest cohort dedicated to elderly Caucasian patients with NSCLC harboring activating EGFR mutations. This population was fragile: $45.3 \%$ of patients needed assistance at home, $28.4 \%$ had performance status 3-4 and their mean age was 83.9 years. Nevertheless, there was a clear benefit of EGFR TKIs in terms of survival. The ORR and the disease control rate were $63.3 \%$ and $78.9 \%$, respectively. Median PFS and median OS were 11.9 months and 20.9 months, respectively. These results are in line with previous studies performed in Asian elderly patients and with a recent meta-analysis [19-21, 24].

Thus, Inoue et al reported that elderly patients or patients with poor performance status with advanced NSCLC harboring EGFR mutation could benefit from gefitinib treatment [19]. The ORR in these 30 patients was $66 \%$ and the disease control rate was $90 \%$. The median PFS and median OS were 6.5 and 17.8 months, respectively. Some patients became eligible to a secondline chemotherapy treatment beyond disease progression. The authors concluded that examination of EGFR mutations as a biomarker was recommended in this patient population that was considered ineligible to chemotherapy because of their age or poor PS.

In another Asian prospective study, Maemondo et al reported efficacy results in 31 elderly patients with an age from 75 to 87 years with advanced NSCLC associated to activating EGFR mutations treated in first line by gefitinib [20]. The ORR was $74 \%$ and the disease control rate was $90 \%$; the median PFS was 12.3 months. The authors concluded that considering the strong antitumor activity of gefitinib and its mild toxicity, first-line EGFR TKI might be preferable to standard chemotherapy for the elderly population.

The Asian study of Tateishi et al retrospectively analyzed the efficacy and safety of gefitinib in 55 patients from 75 to 94 years [21]. The ORR and disease control rate were $72.7 \%$ and $92.7 \%$, respectively; the PFS and OS were 13.8 and 29.1 months, respectively.

The meta-analysis of Roviello et al reported the pooled results of five clinical trials with the use of EGFR TKI in EGFR-mutated NSCLC in first line [24]. Four phase III studies and one phase IIb study were included in the analysis for a total of 1381 patients $[15,18,25-$ 27]. Except the EURTAC study who included European patients and the LUX-Lung 7 studies who included both European and Asian patients, the other studies included

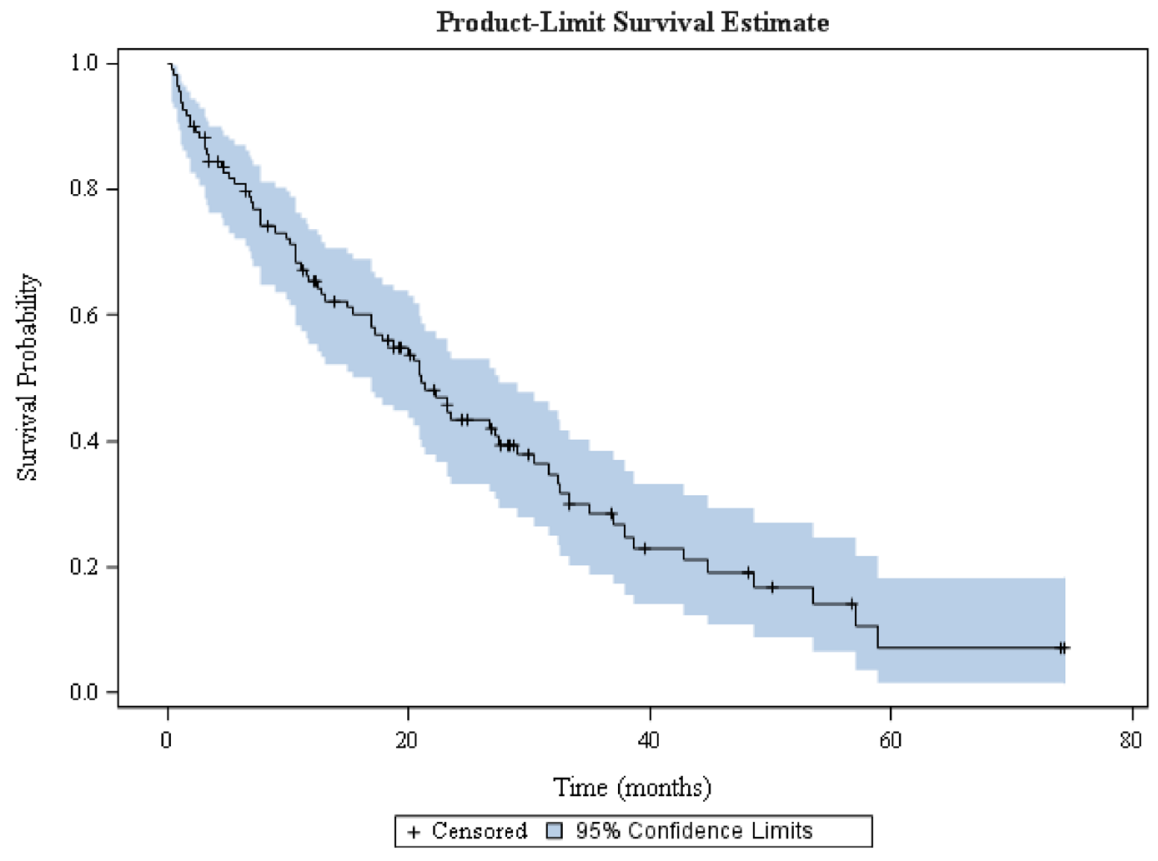

Figure 2: Overall survival in octogenarian patients with EGFR-mutated NSCLC treated with EGFR TKI. 
exclusively Asian patients. Of interest, EGFR TKIs were more effective in prolonging PFS in elderly patients $(\geq 65$ years), with HR $0.39(p=0.008)$ compared with younger patients $(<65$ years) with HR $0.48(p=0.04)$. In our study, $25.4 \%$ of patients continued EGFR TKI treatment after progression for a median of 4 months. These results were in line with studies $[28,29]$ suggesting under certain circumstances, that TKI treatment continuation after RECIST progression is an acceptable option in EGFRmutated NSCLC patients.

Safety data's in this octogenarian population were consistent with adverse events reported in phase III trials and in younger patients [13-18]. Cutaneo-mucous toxicity was reported in $66.7 \%$ of patients and digestive toxicity (diarrhea) in $56.0 \%$. In the study of Maemondo et al rash was reported in $71.1 \%$ of patients treated with gefitinib and diarrhea in $34.2 \%$ [20]. In the study of Zhou et al, rash was reported in $73 \%$ of patients treated with erlotinib and diarrhea in 25\% [15].

Before the arrival of the EGFR TKIs, an age $>75$ years was considered as a major drawback for the use of non-specific cytotoxic agents. Our study clearly shows that patients over 80 years can be treated with EGFR TKI with results that were satisfactory in term of efficacy and safety. Of note, comorbidities and geriatric assessment were insufficiently considered:only $14.0 \%$ of patients with a Charlson comorbidity index and $35.1 \%$ with a geriatric assessment. Even if, in France, it is recommended to perform a geriatric assessment for elderly patients with cancer, $\geq 75$ years old and with a G8 questionnaire score $\leq 14 / 17$. This was not always done most of the time by lack of geriatricians resource, and probably also because the treatment was an oral targeted therapy and not an intravenous chemotherapy. Yet, our group showed in a large phase III randomized study that a geriatric assessment, performed by the pneumo-oncologists, improved the tolerance to chemotherapy in elderly patients treated for advanced lung cancer [30]. Additional studies are needed to assess the impact of geriatric assessment in patients receiving oral cancer treatment, more particularly EGFR TKIs and also to identify geriatric parameters associated with tolerance and/or survival.

About three out of four patients took a number of medications 3 suggesting potential drug interactions with EGFR TKIs. A careful search must be systematically performed in order to improve the efficacy and safety of these treatments [31].

This study has some limitations. The data were recorded retrospectively from patient medical files. These records were not designed for this analysis and the quality of data can be questioned, more particularly for adverse events that could have been underestimated. Patients were selected if they could give their consent (an exemption was obtained for dead patient). Therefore, we cannot exclude a bias with patients lost to follow-up. This possible bias is probably limited since patients over 80 years with EGFR-mutated NSCLC and treated by EGFR TKI were not numerous in each center and they benefited from a very regular follow-up. Another limitation is the absence of comparator group. Finally, considering the inclusion period, mechanisms of resistance to EGFR TKIs that led to progression were not explored as the current recommendations.

In conclusion, in this real-world analysis, octogenarians with EGFR-mutated advanced NSCLC treated by EGFR TKI had clinical outcomes and toxicity profile comparable to younger patients in previous studies. Therefore, elderly should not be a limiting factor for EGFR TKI treatment. Geriatric assessment appeared nevertheless to be underused in this population.

\section{MATERIALS AND METHODS}

\section{Study design and patients}

OCTOMUT was an observational multicentric retrospective study performed in French centers belonging to the French Group of Lung Cancer (GFPC). GFPC is a non-profit federation of university hospitals, general hospitals or healthcare centers that manage patients with thoracic cancers.

Main inclusions criteria's were patients aged 80 and older with EGFR-mutated advanced NSCLC treated with EGFR TKI between January 1, 2011 and March 31, 2015 whatever the line of treatment. Patients were chronologically enrolled during the selection period. Data were retrospectively obtained from medical records.

The study was conducted in accordance with the Declaration of Helsinki and was approved by local independent Ethics Committee (Saint-Etienne University Hospital; IRBN 112016/CHUSTE). Written informed consent was obtained from each patient. For dead patients, an exemption of family consent was obtained from the National Commission for Data Protection and Liberties (CNIL).

\section{Study endpoints}

The primary endpoint was OS and the main secondary endpoints were progression-free survival (PFS); best response according to RECIST 1.1 criteria; toxicity according to NCIC-CTC toxicity criteria (version 4.0) [22].

\section{Statistical analyses}

It was planned to enroll 100 patients. In the previous Asian studies of Maemondo et al [20] and Tateishi et al [21], 31 and 55 patients were included. Moreover, an 
exploratory analysis performed over the period 2010-2012 in a limited number of GFPC centers retrieved 34 patients $\geq 80$ years treated with EGFR TKI. Therefore, it was calculated that 30 GFPC centers would be able to enroll 100 patients. The analysis was essentially descriptive and no formal hypothesis was tested. Qualitative data were described by their frequency, percentage and 95\% confidence interval (CI). Quantitative data were described by their mean and standard deviation or median and interquartile range. Analyses of OS and PFS were conducted using the Kaplan-Meier method. For OS, timeto-event was from the date of the histological diagnosis to the date of death. For PFS, time-to-event was from the first day of TKI treatment to the date of progression or death. Analyses were performed using SAS software version 9.2 (SAS Institute, Inc., Cary, North Carolina, US).

\section{Abbreviations}

TKIs: tyrosine-kinase inhibitors; NSCLC: non-small cell lung cancer; GFPC: French Group of Lung Cancer; ESMO: European Society for Medical Oncology; PFS: progression-free survival; OS: overall survival; ADL: Activities of Daily Living; IADL: Instrumental Activities of Daily Living; MMS: Mini Mental State.

\section{Authors' contribution}

$\mathrm{RC}, \mathrm{CC}$ and JBA are the coordinating investigators of the study, GR, GL substantial contributions to the conception and design of the trial, $\mathrm{RC}, \mathrm{CC}$ and JBA drafted the manuscript, and GF, TL, VF revised the manuscript critically for important intellectual content. FG, DH, FG, DH made substantial contributions to the conception and design of the trial, drafted the manuscript, and revised the manuscript critically. All authors read and approved the final manuscript.

\section{CONFLICTS OF INTEREST}

Corre R, Gervais R, Chouaid C, Descourt R, Doubre $\mathrm{H}$, and J.B. Auliac received fees for attending scientific meetings, speaking, organizing research or consulting from AstraZeneca, Boehringer Ingelheim, and Hoffman la Roche.

Greillier L, Guisier F, Tassy L, Vinas F, Lamy R, Fraboulet $\mathrm{G}$ declare no conflict of interest.

\section{FUNDING}

This work was supported by academic grants from Astra Zeneca. The sponsors had no role in the design or performance of the study, data analysis or manuscript preparation.

\section{REFERENCES}

1. Ferlay J, Shin HR, Bray F, Forman D, Mathers C, Parkin DM. Estimates of worldwide burden of cancer in 2008: GLOBOCAN 2008. Int J Cancer. 2010;127:2893-917.

2. Altekruse S, Kosary C, Krapcho M, Neyman N, Aminou R, Waldron W, Ruhl J, Howlader N, Tatalovich Z, Cho H, Mariotto A, Eisner MP, Lewis DR, et al. SEER Cancer Statistics Review, 1975-2007, National Cancer Institute. Bethesda, MD, http://seer.cancer.gov/csr/1975_2007/, based on November 2009 SEER data submission, posted to the SEER web site, 2010.

3. Thakkar JP, McCarthy BJ, Villano JL. Age-specific cancer incidence rates increase through the oldest age groups. Am J Med Sci. 2014;348:65-70.

4. Pallis AG, Gridelli C, Wedding U, Faivre-Finn C, Veronesi G, Jaklitsch M, Luciani A, O'Brien M. Management of elderly patients with NSCLC; updated expert's opinion paper: EORTC Elderly Task Force, Lung Cancer Group and International Society for Geriatric Oncology. Ann Oncol. 2014;25:1270-83.

5. Quoix E, Zalcman G, Oster JP, Westeel V, Pichon E, Lavolé A, Dauba J, Debieuvre D, Souquet PJ, Bigay-Game L, Dansin E, Poudenx M, Molinier O, et al. Carboplatin and weekly paclitaxel doublet chemotherapy compared with monotherapy in elderly patients with advanced non-smallcell lung cancer: IFCT-0501 randomised, phase 3 trial. Lancet. 2011;378:1079-88.

6. Effects of vinorelbine on quality of life and survival of elderly patients with advanced non-small-cell lung cancer. The Elderly Lung Cancer Vinorelbine Italian Study Group. J Natl Cancer Inst. 1999;91:66-72.

7. Kudoh S, Takeda K, Nakagawa K, Takada M, Katakami N, Matsui K, Shinkai T, Sawa T, Goto I, Semba H, Seto T, Ando M, Satoh T, et al. Phase III study of docetaxel compared with vinorelbine in elderly patients with advanced non-small-cell lung cancer: results of the West Japan Thoracic Oncology Group Trial (WJTOG 9904). J Clin Oncol. 2006;24:3657-63.

8. Quoix E, Breton JL, Ducolone A, Mennecier B, Depierre A, Lemarié E, Moro-Sibilot D, Germa C, Neidhardt AC. First line chemotherapy with gemcitabine in advanced nonsmall cell lung cancer elderly patients: a randomized phase II study of 3-week versus 4-week schedule. Lung Cancer. 2005;47:405-12.

9. Shepherd FA, Rodrigues Pereira J, Ciuleanu T, Tan EH, Hirsh V, Thongprasert S, Campos D, Maoleekoonpiroj S, Smylie M, Martins R, van Kooten M, Dediu M, Findlay $\mathrm{B}$, et al. Erlotinib in previously treated non-small-cell lung cancer. N Engl J Med. 2005;353:123-32.

10. Wheatley-Price P, Ding K, Seymour L, Clark GM, Shepherd FA. Erlotinib for advanced non-small-cell lung cancer in the elderly: an analysis of the National Cancer Institute of Canada Clinical Trials Group Study BR.21. J Clin Oncol. 2008;26:2350-7. 
11. Lynch TJ, Bell DW, Sordella R, Gurubhagavatula S, Okimoto RA, Brannigan BW, Harris PL, Haserlat SM, Supko JG, Haluska FG, Louis DN, Christiani DC, Settleman $\mathrm{J}$, et al. Activating mutations in the epidermal growth factor receptor underlying responsiveness of non-small-cell lung cancer to gefitinib. N Engl J Med. 2004;350:2129-39.

12. Mok TS, Wu YL, Thongprasert S, Chu DT, Saijo N, Sunpaweravong P, Han B, Margono B, Ichinose Y, Nishiwaki Y, Ohe Y, Yang JJ, Chewaskulyong B, et al. Gefitinib or carboplatin-paclitaxel in pulmonary adenocarcinoma. N Engl J Med. 2009;361:947-57.

13. Han JY, Park K, Kim SW, Lee DH, Kim HY, Kim HT, Ahn MJ, Yun T, Ahn JS, Suh C, Lee JS, Yoon SJ, Han JH, et al. First-SIGNAL: first-line single-agent iressa versus gemcitabine and cisplatin trial in never-smokers with adenocarcinoma of the lung. J Clin Oncol. 2012;30:1122-8.

14. Maemondo M, Inoue A, Kobayashi K, Sugawara S, Oizumi $\mathrm{S}$, Isobe $\mathrm{H}$, Gemma A, Harada M, Yoshizawa H, Kinoshita I, Fujita Y, Okinaga S, Hirano H, et al. Gefitinib or chemotherapy for non-small-cell lung cancer with mutated EGFR. N Engl J Med. 2010;362:2380-8.

15. Zhou C, Wu YL, Chen G, Feng J, Liu XQ, Wang C, Zhang S, Wang J, Zhou S, Ren S, Lu S, Zhang L, Hu C, et al. Erlotinib versus chemotherapy as first-line treatment for patients with advanced EGFR mutation-positive non-smallcell lung cancer (OPTIMAL, CTONG-0802): a multicentre, open-label, randomised, phase 3 study. Lancet Oncol. 2011;12:735-42.

16. Rosell R, Moran T, Queralt C, Porta R, Cardenal F, Camps C, Majem M, Lopez-Vivanco G, Isla D, Provencio M, Insa A, Massuti B, Gonzalez-Larriba JL, et al. Screening for epidermal growth factor receptor mutations in lung cancer. N Engl J Med. 2009;361:958-67.

17. Sequist LV, Yang JC, Yamamoto N, O’Byrne K, Hirsh V, Mok T, Geater SL, Orlov S, Tsai CM, Boyer M, Su WC, Bennouna J, Kato T, et al. Phase III study of afatinib or cisplatin plus pemetrexed in patients with metastatic lung adenocarcinoma with EGFR mutations. J Clin Oncol. 2013;31:3327-34.

18. Wu YL, Zhou C, Hu CP, Feng J, Lu S, Huang Y, Li W, Hou M, Shi JH, Lee KY, Xu CR, Massey D, Kim M, et al. Afatinib versus cisplatin plus gemcitabine for first-line treatment of Asian patients with advanced non-small-cell lung cancer harbouring EGFR mutations (LUX-Lung 6): an open-label, randomised phase 3 trial. Lancet Oncol. 2014; 15:213-22.

19. Inoue A, Kobayashi K, Usui K, Maemondo M, Okinaga S, Mikami I, Ando M, Yamazaki K, Saijo Y, Gemma A, Miyazawa H, Tanaka T, Ikebuchi K, et al. Firstline gefitinib for patients with advanced non-small-cell lung cancer harboring epidermal growth factor receptor mutations without indication for chemotherapy. J Clin Oncol. 2009;27:1394-400.

20. Maemondo M, Minegishi Y, Inoue A, Kobayashi K, Harada M, Okinaga S, Morikawa N, Oizumi S, Tanaka T, Isobe H,
Kudoh S, Hagiwara K, Nukiwa T, et al. First-line gefitinib in patients aged 75 or older with advanced non-small cell lung cancer harboring epidermal growth factor receptor mutations: NEJ 003 study. J Thorac Oncol. 2012;7:1417-22.

21. Tateishi K, Ichiyama T, Hirai K, Agatsuma T, Koyama S, Hachiya T, Morozumi N, Shiina T, Koizumi T. Clinical outcomes in elderly patients administered gefitinib as firstline treatment in epidermal growth factor receptor-mutated non-small-cell lung cancer: retrospective analysis in a Nagano Lung Cancer Research Group study. Med Oncol. 2013;30:450.

22. Eisenhauer EA, Therasse P, Bogaerts J, Schwartz LH, Sargent D, Ford R, Dancey J, Arbuck S, Gwyther S, Mooney M, Rubinstein L, Shankar L, Dodd L, et al. New response evaluation criteria in solid tumours: revised RECIST guideline (version 1.1). Eur J Cancer. 2009;45:228-47.

23. Rowe J, Patel S, Mazo-Canola M, Parra A, Goros M, Michalek J, Kelly K, Weitman S, Karnad A. An evaluation of elderly patients $(>/=70$ years old) enrolled in Phase I clinical trials at University of Texas Health Science Center at San Antonio-Cancer Therapy Research Center from 2009 to 2011. Journal of geriatric oncology. 2014;5:65-70.

24. Roviello G, Zanotti L, Cappelletti MR, Gobbi A, Dester M, Paganini G, Pacifico C, Generali D, Roudi R. Are EGFR tyrosine kinase inhibitors effective in elderly patients with EGFR-mutated non-small cell lung cancer? Clin Exp Med. 2017 Apr 8. [Epub ahead of print].

25. Rosell R, Carcereny E, Gervais R, Vergnenegre A, Massuti B, Felip E, Palmero R, Garcia-Gomez R, Pallares C, Sanchez JM, Porta R, Cobo M, Garrido P, et al. Erlotinib versus standard chemotherapy as first-line treatment for European patients with advanced EGFR mutation-positive non-small-cell lung cancer (EURTAC): a multicentre, openlabel, randomised phase 3 trial. Lancet Oncol. 2012;13:23946.

26. Park K, Tan EH, O`Byrne K, Zhang L, Boyer M, Mok T, Hirsh V, Yang JC, Lee KH, Lu S, Shi Y, Kim SW, Laskin $\mathrm{J}$, et al. Afatinib versus gefitinib as first-line treatment of patients with EGFR mutation-positive non-small-cell lung cancer (LUX-Lung 7): a phase 2B, open-label, randomised controlled trial. Lancet Oncol. 2016;17:577-89.

27. Urata Y, Katakami N, Morita S, Kaji R, Yoshioka H, Seto T, Satouchi M, Iwamoto Y, Kanehara M, Fujimoto D, Ikeda N, Murakami H, Daga H, et al. Randomized Phase III Study Comparing Gefitinib With Erlotinib in Patients With Previously Treated Advanced Lung Adenocarcinoma: WJOG 5108L. J Clin Oncol. 2016;34:3248-57.

28. Park K, Yu CJ, Kim SW, Lin MC, Sriuranpong V, Tsai CM, Lee JS, Kang JH, Chan KC, Perez-Moreno P, Button P, Ahn MJ, Mok T. First-Line Erlotinib Therapy Until and Beyond Response Evaluation Criteria in Solid Tumors Progression in Asian Patients With Epidermal Growth Factor Receptor Mutation-Positive Non-Small-Cell Lung Cancer: The ASPIRATION Study. JAMA oncology. 2016;2:305-12. 
29. Auliac JB, Fournier C, Audigier Valette C, Perol M, Bizieux A, Vinas F, Decroisette Phan van Ho C, Bota Ouchlif S, Corre R, Le Garff G, Fournel P, Baize N, Lamy R, et al. Impact of Continuing First-Line EGFR Tyrosine Kinase Inhibitor Therapy Beyond RECIST Disease Progression in Patients with Advanced EGFR-Mutated Non-Small-Cell Lung Cancer (NSCLC): Retrospective GFPC 04-13 Study. Target Oncol. 2016;11:167-74.

30. Corre R, Greillier L, Le Caer H, Audigier-Valette C, Baize N, Bérard H, Falchero L, Monnet I, Dansin E, Vergnenègre A, Marcq M, Decroisette C, Auliac JB, et al. Use of a Comprehensive Geriatric Assessment for the Management of Elderly Patients With Advanced Non-Small-Cell Lung Cancer: The Phase III Randomized ESOGIA-GFPC-GECP 08-02 Study. J Clin Oncol. 2016;34:1476-83.
31. Mir O, Blanchet B, Goldwasser F. Drug-induced effects on erlotinib metabolism. N Engl J Med. 2011;365:379-80. 